\title{
KORELASI ANTARA KEMAMPUAN MENGGAMBAR SKETSA DAN MENGGAMBAR PERSPEKTIF DENGAN HASIL BELAJAR MENGGAMBAR BENTUK PADA SISWA KELAS XI SMAN 2 MEDAN
}

\author{
Dini Sumarni $^{1^{*}}$, R. Triyanto ${ }^{2 *}$, Sugito ${ }^{3 *}$ Dwi Budiwiwaramulja ${ }^{4 *}$ \\ Program Studi Pendidikan Seni Rupa Jurusan Seni Rupa Fakultas Bahasa dan Seni \\ Universitas Negeri Medan \\ Jl. Willem Iskandar Pasar V Medan Estate, Kec, Percut Sei Tuan, Kab. Deli Serdang, Kode Pos 20371 \\ Sumatera Utara. Indonesia \\ Email: dinisumarni1103@gmail.com
}

\begin{abstract}
Abstrak
Penelitian ini bertujuan untuk mengetahui apakah ada korelasi antara kemampuan menggambar sketsa dan menggambar perspektif dengan hasil menggambar bentuk. Adapun populasi dalam penelitian ini adalah seluruh siswa kelas XI SMAN 2 Medan yang mengikuti pelajaran menggambar bentuk dengan jumlah 139 siswa dan sampel yaitu kelas XI Mipa 11 yang berjumlah 26 orang dengan menggunakan teknik clusterrandom sampling. Metode penelitian ini menggunakan penelitian correlational research. Hasil temuan penelitian ini menunjukkan bahwa terdapat korelasi kemampuan menggambar sketsa dan menggambar perspektif dengan hasil belajar menggambar bentuk, yang dibuktikan dengan $\mathrm{F}_{\text {hitung }}=23,63$ untuk dk $=n-k-1=23 \mathrm{a}=0,05 \mathrm{~F}_{\text {tabel }}=3,42$ ternyata $\mathrm{F}_{\text {hitung }}>\mathrm{F}_{\text {tabel }}(23,63>3,42)$. Besar hubungan antara kemampuan menggambar sketsa dan menggambar perspektif dengan hasil belajar menggambar bentuk berkorelasi yaitu 0,73 , dan besar sumbangan (kontribusi) yaitu sebesar 53\%.
\end{abstract}

Kata Kunci: korelasi, perspektif, sketsa, bentuk.

\begin{abstract}
This study aims to fine out whether there is an correlation of ability draw a sketches and draw perspective on the learning outcomes of drawing shapes. The population in this study were all grade XI student of SMKN 2 Medan who took a lesson in drawing shapes with 139 and sample of XI Mipa 11 class totaling 26 students were taken randomly with using a cluster random sampling technique. This study method uses correlation research. The results of this study indicate that there is a correlation between the ability to draw sketches and draw perspective with the results of learning to draw shapes, which is proved by $F_{\text {count }}=23,63$ fordk $=n-k-1=23 \alpha=0,05 F_{\text {table }}=3,42$ so, $F_{\text {count }}$ $>F_{\text {table }}(23,63>3,42)$. Great correlation between draw sketches and draw perspective with the results of learning to draw shapes is 0,73 and many influence (contribution) is 53\%.
\end{abstract}

Keywords: correlation, perspective, sketch, shape.

\section{PENDAHULUAN}

Seni Budaya dibagi menjadi beberapa bagian, antaranya adalah seni rupa. Seni rupa adalah bidang studi yang mengasah kreativitas anak didik dalam berolah seni. Pada kurikulum seni budaya SMA disebutkan bahwa siswa dapat mengekspresikan diri melalui karya seni rupa. Salah satunya adalah dengan menggambar bentuk. Yakni suatu kegiatan menggambarkan objek model yang dilihat langsung ke atas bidang gambar dengan keutamaan kemiripan terhadap model tersebut.

Namun dari pengamatan hasil belajar menggambar bentuk yang diperoleh siswa belum menunjukkan pencapaian hasil yang dapat memenuhi harapan sesuai konsep tujuan pembelajaran seni, khususnya seni rupa. Hal ini ditunjukkan dengan data rata-rata hasil belajar yang terdapat dalam buku nilai harian siswa yang dimiliki oleh guru bidang studi yaitu sebesar 66,8 sedangkan KKM pelajaran seni budaya adalah 75 .

Dalam pembelajaran menggambar bentuk, peneliti melihat siswa sering mengalami kesulitan untuk mendapatkan bentuk proporsi yang baik sesuai dengan model. Banyak hasil gambar yang belum memenuhi syarat sebagai gambar bentuk yang baik.

Sehubungan dengan hal tersebut di atas, didasarkan pada pengamatan yang telah diseleksi dan dilakukan terhadap karya-karya gambar bentuk siswa, masih 
banyak ditemukan kelemahan-kelemahan yang sifatnya sangat mendasar bagi keutuhan sebuah karya gambar bentuk. Kelemahan yang dimaksud seperti kurang mampu memindahkan bentuk model ke atas bidang gambar dan kurang mampu membuat arsiran gelap terang. Banyaknya gambar yang tidak sesuai dengan prinsip-prinsip seni rupa. Hal demikian terjadi, karena siswa kurang memiliki wawasan dan kemampuan dalam menggambar sketsa dan menggambar perspektif.

\section{KAJIAN TEORI}

\section{Korelasi}

Menurut Sudjana (2005:367) “Analisis korelasi adalah teknik statistik yang membahas tentang derajat hubungan antara variable-variabel". Selain itu, Usman dan Purnomo dalam Sugito, (2017:64) mengatakan "Analisis korelasi adalah istilah statistik yang menyatakan derajat hubungan linear antara dua variable atau lebih".

\section{Kemampuan}

Pengertian kemampuan siswa atau kompetensi siswa terdiri atas tiga aspek yaitu pengetahuan (kognitif), keterampilan (psikomotor), sikap (afektif) sebagaimana yang tertulis dalam buku ketentuan umum kurikulum Pendidikan Seni Rupa (2004) menerjemahkan pengertian kompetensi secara sederhana, yaitu "kompetensi merupakan pengetahuan, keterampilan, sikap, dan nilai yang diwujudkan dalam kebiasaan dan bertindak sebagai karakteristik yang mendasar" (Suciati:2014).

\section{Sketsa}

Seorang ahli mengatakan "tujuan sketsa adalah mengabadikan esensi dari suatu hal yang nyata"(Wang, 2002:71). Ia mengatakan membuat sketsa harus cepat dan tangkas, gambar sketsa juga tidak harus mendetail. Kemudian pendapat lain mendefinisikan "sketsa adalah bagan atau rencana bagi sebuah lukisan"(Kusnadi, 1987: 27). "Sketsa adalah gambar rancangan dari sebuah model, yang nantinya akan dilanjutkan dengan mengarsir untuk menghasilkan bentuk yang sesungguhnya. Sketsa juga berupa garis-garis halus yang mewakili kontur setiap objek model" (Laseau, 2000:62).

\section{Perspektif}

Menurut Leonardo "Perspektif pada dasarnya masih merupakan hal yang berhubungan dengan ilmu optik secara substansial, yaitu untuk pengamatan langsung dan hukum-hukum yang menentukannya" (Leonardo dalam Syafii, 2002:33). Perspektif pernah juga diartikan sebagai gambar pemandangan dengan posisi
Gorga : Jurnal Seni Rupa

Volume 09 Nomor 01 Januari-Juni 2020

p-ISSN: 2301-5942 | e-ISSN: 2580-2380

piktorial sebagaimana contoh pemandangan perkampungan, gunung, laut, pulau, lembah, benteng, perkotaan, dan rumah sebagai perspektif natural (Troilli dalam Syafii, 2002:33). Dalam hal ini Syafii (2002:33) menyatakan bahwa "gambar perspektif merupakan representasi grafis dengan diagramdiagram linier figur benda (tunggal atau jamak), yang biasanya berada pada pemukaan datar, dengan menggunakan metode Proyeksi Sentral. Dengan pengertian lain, gambar perspektif mengacu pada suatu system (cara) dalam mempresentasikan objek riel atau imajiner pada bidang dua dimensional, yang daripadanya digunakan untuk menunjukan kedalaman ruang (keruangan) yang tiga dimensional".

\section{Menggambar Bentuk}

Menggambar adalah melukiskan suatu objek ke bidang gambar (kertas), contohnya gambar bentuk berupaya menggambar bentuk objek yang menjadi model dan memindahkannya ke atas bidang gambar sesuai dengan kenyataannya (Margono, 2007:66). Pada buku lain juga dikatakan "bentuk adalah lengkung; lentur, bangun; gambar, rupa; wujud, system; susun" (Moeliono 2002:183). Maka menggambar bentuk adalah suatu kegiatan memindahkan objek model yang dilihat langsung ke atas bidang gambar dengan lebih mengutamakan kemiripan terhadap model tersebut.

\section{METODE PENELITIAN}

Setiap penelitian harus menggunakan metode untuk mencapai suatu tujuan. Penelitian ini bertujuan untuk mengetahui ada atau tidaknya korelasi antarakemampuan menggambar sketsa dan menggambar perspektif dengan hasil belajar menggambar bentuk siswa kelas XI SMAN 2 Medan. Maka jenis penelitian ini adalah "correlational research" yang melibatkan satu kelas dan kemudian diberi tiga materi pembelajaran yang berbeda. Sampel penelitian terlebih dahulu diberikan test awal yaitu materi pembelajaran menggambar sketsa dan menggambar perspektif lalu selanjutnya diberikan test akhir yaitu menggambar bentuk.

\section{HASIL DAN PEMBAHASAN \\ 1.Hasil}

Hasil penelitian 1 secara umum dalam menggambar sketsa siswa kelas XI MIPA 11 SMA Negeri 2 Medan berada pada kategori B (Baik) sebanyak 11 orang, dengan jumlah nilai 2185 dan nilai rata - rata $=$ 84.Sketsa yang baik adalah gambar yang mampu mewakili suatu objek dengan garis yang natural, memiliki ketepatan bentuk yang sesuai dan komposisi 
gambar yang baik.Maka pada penelitian 1 siswa dinyatakan tuntas untuk memenuhi ktiteria tersebut.

Hasil penelitian 2secara umum dalam menggambar perspektif siswa kelas XI MIPA 11 SMA Negeri 2 Medan berada pada kategori B (Baik) sebanyak 12 orang, dengan jumlah nilai 2128 dan nilai rata - rata $=$ 81,8.Gambar perspektif dikatakan baik apabila garis sejajar yang mengarah ke horizon akan bertemu di satu titik hilang yang berada pada garis horizon, selain itu benda besar semakin sejauh semakin kecil dan benda tinggi semakin rendah. Kemudian warna benda pada gambar pespektif semakin jauh semakin pucat.Ternyata pada penelitian 2 siswa dinyatakan tuntas untuk memenuhi ktiteria tersebut.

Kemudian penelitian 3 secara umum dalam menggambar bentuk siswa kelas XI MIPA 11 SMA Negeri 2 Medan berada pada kategori B (Baik) sebanyak 11 orang, dengan jumlah nilai 2194 dan nilai rata - rata $=84,4$.Menggambar bentuk dikatakan baik apabila siswa mampu memindahkan objek model ke atas bidang gambar dengan kemiripan sesuai model.Hal tersebut tidak lepas dari keberhasilan siswa menerapkan prinsip-prinsip menggambar bentuk yang baik seperti komposisi, proporsi dll.Ternyata pada penelitian 3 siswa dinyatakan tuntas untuk memenuhi ktiteria tersebut.

\section{Pembahasan}

\section{1). Uji Normalitas}

Untuk menguji normalitas data digunakan uji lilifors yang bertujuan untuk mengetahui apakah penyebaran data hasil penelitian memiliki sebaran data yang berdistribusi normal atau tidak. Sampel berdistribusi normal jika dipenuhi $L_{\text {hitung }}<L_{\text {tabel }}$ pada taraf signifikan $\alpha=0,05$. Uji normalitas data kemampuan hasil belajar menggambar sketsa siswa diperoleh $L_{\text {hitung }}=0,172$, menggambar perspektif $L_{\text {hitung }}=$ 0,154 dan menggambar bentuk dipeloreh $L_{\text {hitung }}=$ 0,144 dan $\mathrm{n}=26$, diperoleh nilai kritis untuk uji Normalitas harga $L_{\text {tabel }}=0,173$. Karena $L_{\text {hitung }}<L_{\text {tabel }}$, ini berarti data menggambar sketsa, menggambar perspektif dan menggambar bentuk berdistribusi normal. Secara ringkas dapat dilihat pada tabel berikut:

Tabel 1.Ringkasan Hasil Pengujian Normalitas

\begin{tabular}{|l|c|c|c|}
\hline \multicolumn{1}{|c|}{ Data } & $\mathrm{L}_{\text {hitung }}$ & $\mathrm{L}_{\text {tabel }}$ & Ket \\
\hline Menggambar Sketsa & 0,172 & 0,173 & Normal \\
\hline Menggambar Perspektif & 0,154 & 0,173 & Normal \\
\hline Menggambar Bentuk & 0,144 & 0,173 & Normal \\
\hline
\end{tabular}

Gorga : Jurnal Seni Rupa

Volume 09 Nomor 01 Januari-Juni 2020

p-ISSN: 2301-5942 | e-ISSN: 2580-2380

Uji linieritas menggunakan metode kuadrat terkecil dan dilanjut dengan analisis of variance(ANOVA). Hasil persamaan regresi $\mathrm{X}_{1}$ atas $\mathrm{Y}$ adalah $\bar{Y}=41,43+$ $0,5 \mathrm{X}_{1}$ dan $\mathrm{X}_{2}$ atas $\mathrm{Y}$ adalah $\bar{Y}=79,01+0,6 \mathrm{X}_{2}$ diperoleh hasil koefisien arah $=0,5$ dan 0,6 yang bertanda positif, artinya menandakan bahwa rata-rata kemampuan menggambar sketsa dan menggambar perspektif diprediksi (diramalkan) memberi kenaikan pada kemampuan menggambar bentuk sebesar 0,5 dan 0,6 ( $50 \%$ dan $60 \%$ ).

Tabel 2.Rangkuman Uji Linieritas Antara $X_{1}$ dengan $Y$

\begin{tabular}{|l|c|c|c|c|c|}
\hline $\begin{array}{c}\text { Sumber } \\
\text { Variasi }\end{array}$ & JK & DK & RJK & $F_{\text {Hitung }}$ & $F_{\text {tabel }}$ \\
\hline Total & 186112 & 26 & & & \\
\hline Reg (a) & 185139,85 & 1 & 185139,85 & & \\
Reg (a/b) & 2,79 & 1 & 27,9 & 11,97 & 4,26 \\
Residu & 969,36 & 24 & 40,39 & & \\
\hline Tuna Cocok & $-6959,84$ & 7 & -1160 & 0,06 & 2,62 \\
Galat & 7929,2 & 17 & 440,5 & & \\
\hline
\end{tabular}

Berdasarkan Tabel 2 diperoleh bahwa $F_{\text {tabel }}$ dengan Dk $(7,17)$ pada $\mathrm{a}=0.05$ adalah 2,62 sedangkan $F_{\text {hitung }}$ diperoleh sebesar 0,06 dan ternyata $F_{\text {tabel }}>F_{\text {hitung }}$ sehingga persamaan regresi tersebut linier. Selanjutnya uji signifikan dengan Dk $(1,24)$ pada $a=$ 0.05 diperoleh $F_{\text {tabel }} \quad 4,26$ sedangkan $F_{\text {hitung }}=11,97$ dan ternyata $F_{\text {tabel }}<F_{\text {hitung }}$ sehingga persamaan regresi $\mathrm{X}_{1}$ dan $\mathrm{Y}$ adalah signifikan. Dengan demikian dapat disimpulkan bahwa persamaan regresi $\bar{Y}=41,43+0,5$ $\mathrm{X}_{1}$ mempunyai hubungan yang linier dan signifikan pada taraf kepercayaan $a=0.05$.

Tabel 3.Rangkuman Uji Linieritas Antara $X_{1}$ dengan $Y$

\begin{tabular}{|l|c|c|c|c|c|}
\hline $\begin{array}{c}\text { Sumber } \\
\text { Variasi }\end{array}$ & JK & DK & RJK & $F_{\text {Hitung }}$ & $F_{\text {tabel }}$ \\
\hline Total & 186112 & 26 & & & \\
\hline Reg (a) & 185139,85 & 1 & 185139,85 & & \\
Reg (a/b) & 27,9 & 1 & 27,9 & 7,09 & 4,26 \\
Residu & 944,25 & 24 & 40,39 & & \\
\hline Tuna Cocok & $-6984,95$ & 6 & -1164 & 2,64 & 2,66 \\
Galat & 7929,2 & 18 & 440,5 & & \\
\hline
\end{tabular}

Berdasarkan Tabel 3 diperoleh bahwa $F_{\text {tabel }}$ dengan Dk $(6,18)$ pada $\mathrm{a}=0.05$ adalah 2,66 sedangkan $F_{\text {hitung }}$ diperoleh sebesar 2,64 dan ternyata $F_{\text {tabel }}>F_{\text {hitung }}$ sehingga persamaan regresi tersebut linier. Selanjutnya uji signifikan dengan $\mathrm{Dk}(1,24)$ pada $\mathrm{a}=$ 0.05 diperoleh $F_{\text {tabel }} 4,26$ sedangkan $F_{\text {hitung }}=7,09$ dan ternyata $F_{\text {tabel }}<F_{\text {hitung }}$ sehingga persamaan regresi $\mathrm{X}_{2}$ dan $Y$ adalah signifikan. Dengan demikian dapat disimpulkan bahwa persamaan regresi $\bar{Y}=79,01+0,6$ $\mathrm{X}_{2}$ mempunyai hubungan yang linier dan signifikan pada taraf kepercayaan $\mathrm{a}=0.05$.

\section{2).Uji Linieritas}




\section{3).Uji Korelasi}

\section{(1). Besar Hubungan}

Besar hubungan antara kemampuan menggambar sketsa dengan hasil belajar menggambar bentuk diperoleh $\mathrm{r}_{\text {hitung }}=0.58$ berkriteria sedang. Selanjutnya besar hubungan antara kemampuan menggambar perspektif dengan hasil belajar menggambar bentuk diperoleh $\mathrm{r}_{\text {hitung }}=0.56$ berkriteria sedang. Dan besar hubungan antara kemampuan menggambar sketsa dengan kemampuan menggambar perspektif diperoleh $r_{\text {hitung }}=0.86$ berkriteria sangat kuat.

\section{(2). Besar Sumbangan}

Besar sumbangan (kontribusi) antara kemampuan menggambar sketsa dengan hasil belajar menggambar bentuk diperoleh $\mathrm{r}^{2} \quad 0,33$ artinya sebesar $33 \%$. Selanjutnya besar sumbangan (kontribusi) antara kemampuan menggambar perspektif dengan hasil belajar menggambar bentuk diperoleh $\mathrm{r}^{2} 0,31$ artinya sebesar $31 \%$.

\section{4).Uji Signifikan}

Signifikasi hubungan menggambar sketsa dengan hasil belajar menggambar bentuk diperoleh $t_{\text {hitung }}=3,46$ untuk $\mathrm{Dk}=\mathrm{n}-2=24 \mathrm{a}=0.05 t_{\text {tabel }}=1,706$ ternyata $t_{\text {hitung }}>t_{\text {tabel }}(3,46>1,706)$, artinya variabel $\left(\mathrm{X}_{1}\right)$ dan (Y) memiliki hubungan yang sangat signifikan atau berarti. Hubungan menggambar perspektif dengan hasil belajar menggambar bentuk diperoleh $t_{\text {hitung }}=$ 3,29 untuk Dk=n-2=24 a $=0.05 t_{\text {tabel }}=1,706$ ternyata $t_{\text {hitung }}>t_{\text {tabel }}(3,29>1,706)$, artinya variabel $\left(\mathrm{X}_{2}\right)$ dan (Y) memiliki hubungan yang sangat signifikan atau berarti.Kemudian signifikasi hubungan menggambar sketsa dengan menggambar perspektif diperoleh $t_{\text {hitung }}$ $=8,25$ untuk $\mathrm{Dk}=\mathrm{n}-2=24 \mathrm{a}=0.05 t_{\text {tabel }}=1,706$ ternyata $t_{\text {hitung }}>t_{\text {tabel }}(8,25>1,706)$, artinya variabel $\left(\mathrm{X}_{1}\right)$ dan $\left(\mathrm{X}_{2}\right)$ memiliki hubungan yang sangat signifikan atau berarti.

\section{5).Uji Hipotesis}

Berdasarkan hasil perhitungan uji hipotesis diperoleh besar hubungan antara kemampuan menggambar sketsa dan menggambar perspektif dengan hasil belajar menggambar bentuk, besar hubungan diperoleh $\mathrm{r}_{\text {hitung }}=0.73$ berkriteria kuat.

Besar sumbangan (kontribusi) antara kemampuan menggambar sketsa dan menggambar perspektif dengan hasil belajar menggambar bentuk diperoleh $\mathrm{r}^{2}$ $=53 \%$ artinya variabel $X_{1}$ dan $X_{2}$ memberi kontribusi atau masukan (sumbangan) pada variabel $\mathrm{Y}$ rata rata $53 \%$, sisanya $47 \%$ dari variabel lain.
Signifikasi hubungan antara kemampuan menggambar sketsa dan menggambar perspektif dengan hasil belajar menggambar bentuk diperoleh $F_{\text {hitung }}=3,42$ untuk Dk=n-k-1=23 a = $0.05 \quad F_{\text {tabel }}=2,23$ ternyata $F_{\text {hitung }}>F_{\text {tabel }}(3,42>2,23)$, artinya antara variabel $X_{1}$ dan $\mathrm{X}_{2}$ dengan $\mathrm{Y}$ memiliki hubungan yang sangat signifikan atau yang berarti.

\section{KESIMPULAN DAN SARAN \\ 1.Kesimpulan}

Terdapat hubungan yang signifikan antara kemampuan menggambar sketsa dan menggambar perspektif dengan hasil belajar menggambar bentuk.Besar hubungan antara kemampuan menggambar sketsa dan menggambar perspektif dengan hasil belajar menggambar bentuk yaitu 0,73. Besar sumbangan (kontribusi) antara kemampuan menggambar sketsa dan menggambar perspektif dengan hasil belajar menggambar bentuk yaitu sebesar $53 \%$, sehingga besar sumbangan kemampuan menggambar sketsa dan menggambar perspektif terhadap hasil belajar menggambar bentuk memberikan dampak yang positif.

\section{Saran}

Sebaiknya wawasan dan kemampuan tentang menggambar sketsa dan perspektif dapat ditambah lagi pada ranah pembelajaran seni budaya di sekolah, dengan tujuan agar kemampuan menggambar sketsa dan perspektif yang dimiliki bisa memberikan masukan yang lebih besar dalam menunjang kemampuan siswa untuk menggambar bentuk yang lebih baik.

\section{DAFTAR RUJUKAN}

Sudjana. (2005). Metode Statistika. Bandung: PT. Tarsito.

Sugito dan Nelson. (2017). Statistik Pendidikan Seni Rupa. Medan: UNIMED PRESS.

Suciati, (2014).Metode Penelitian Pendidikan. Bandung: Alfabeta

Wang, Thomas C. (2002). Sketsa Pencil. Jakarta: PT.Gelora Aksara Pratama.

Kusnadi. (1987). Sketches By Widayat \& Nyoman Gunarsa. Rudana_Art Gallery.

Lauseau, Paul. (2000). Graphic Thingking For

Architects and Designers. John Wiley \& Sons, Inc.

Syafii. (2002). "Proyeksi Perspektifl"Papara $n$ perkuliahan Mahasiswa. Semarang: Fakultas Bahasa dan Seni Universitas Negeri Semarang

Margono, dkk. (2007). Apresiasi Seni. Jakarta: Yudhitira. 
Moeliono M, Anton. (2002). Telaah Bahasa dan

Sastra. Jakarta: Yayasan Obor

Indonesia. 